\title{
Corrigendum: Insufficient antibody validation challenges oestrogen receptor beta research
}

\author{
Sandra Andersson, Mårten Sundberg, Nusa Pristovsek, Ahmed Ibrahim, Philip Jonsson, Borbala Katona, \\ Carl-Magnus Clausson, Agata Zieba, Margareta Ramström, Ola Söderberg, Cecilia Williams \& Anna Asplund
}

Nature Communications 8:15840 doi: 10.1038/ncomms15840 (2017); Published 15 Jun 2017; Updated 29 Nov 2017

In this Article, two papers are mistakenly listed as having made use of the antibody 14C8 instead of the antibody PPG5/10. In the Discussion section, ref. 45 is incorrectly cited as having shown that the antibody 14C8 works well, and in Fig. 5a, Saunders et al. 2000 is incorrectly depicted as using the 14C8 antibody. Both these papers used antibody PPG5/10 and neither paper includes experiments using 14C8. A corrected version of Fig. 5 appears below as Fig. 1.

\section{(c) (1)}

Open Access This article is licensed under a Creative Commons Attribution 4.0 International License, which permits use, sharing, adaptation, distribution and reproduction in any medium or format, as long as you give appropriate credit to the original author(s) and the source, provide a link to the Creative Commons license, and indicate if changes were made. The images or other third party material in this article are included in the article's Creative Commons license, unless indicated otherwise in

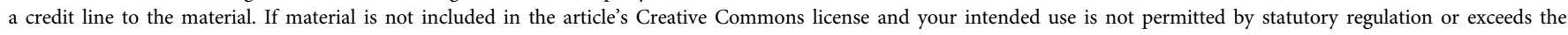
permitted use, you will need to obtain permission directly from the copyright holder. To view a copy of this license, visit http://creativecommons.org/licenses/by/4.0/

(C) The Author(s) 2017 

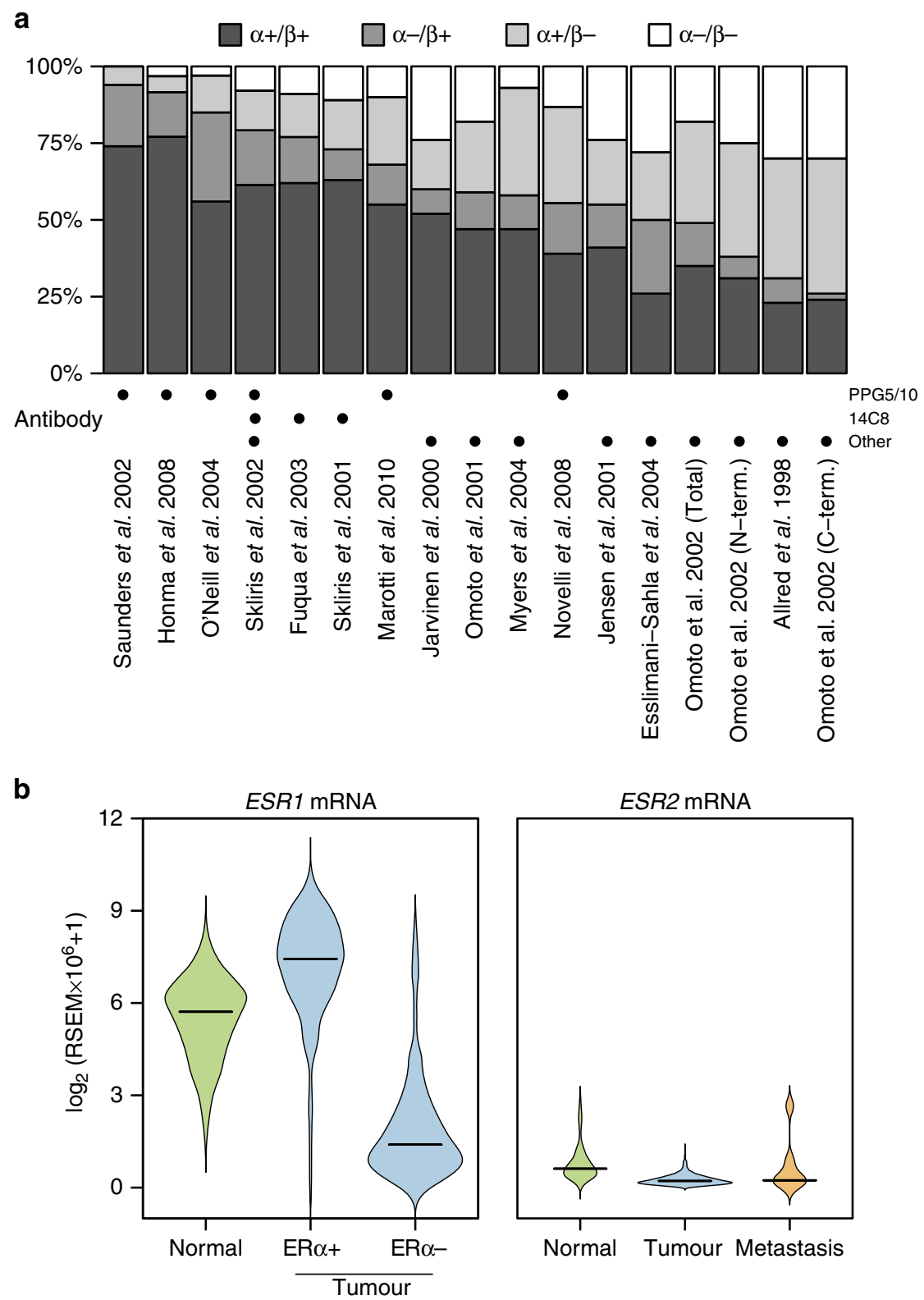

Figure 1 